\title{
Effect of a Leaf Spot Disease Caused by Alternaria alternata on Yield of Sunflower in Greece
}

\author{
Anastasia L. Lagopodi and Costas C. Thanassoulopoulos, Aristotelian University, Faculty of Agriculture, Plant \\ Pathology Laboratory, P.O.B. 269, Thessaloniki, GR 540 06, Greece
}

\begin{abstract}
Lagopodi, A. L., and Thanassoulopoulos, C. C. 1998. Effect of a leaf spot disease caused by Alternaria alternata on yield of sunflower in Greece. Plant Dis. 82:41-44.

Field experiments were conducted during the 1989 to 1993 growing seasons in order to determine the effect of natural infections of Alternaria alternata on yield of sunflower (Helianthus aпnииs). Number of seeds produced per head and seed weight were reduced by 16 to $65 \%$ and 15 to $79 \%$, respectively. Number and weight of seeds produced per head were correlated negatively with disease intensity before anthesis. The fungus overwinters in sunflower leaf residues and may present a yearly problem for sunflower production in some areas.
\end{abstract}

During field surveys in the 1986 growing season, an extensive leaf spot disease was observed in sunflower (Helianthus annuus L.) fields in Thessaloniki, Kilkis, and Halkidiki prefectures of Makedonia in northern Greece. The causal agent was identified as Alternaria alternata (Fries) Keissler (IMI 366417, CBS 639.97, ATCC 201166). The leaf spot disease caused by A. alternata was observed in all cultivated areas in 1986. This disease and charcoal rot, (Macrophomina phaseolina (Tassi) Goid), were the major diseases on the crop (31). Symptoms began as brown zonate spots on basal leaves and progressed to upper leaves. Spots eventually coalesced, and the infected leaves dried up and defoliated. Severity of infections varied from premature declining of lower leaves to extensive defoliation of entire plants. $A$. alternata was the only species of Alternaria isolated from plants in the areas mentioned above, at least until 1991, a year in which sunflower acreage began to decline (1). Isolates of the fungus were highly pathogenic to sunflower $(15,32)$.

Nine Alternaria species have been reported on sunflower, including $A$. helianthi (Hansford) Tubaki and Nishihara, A. alternata, A. zinniae Ellis, A. tenuissima (Fries) Wiltshire, A. leucanthemi Nelen (syn. A. chrysanthemi Simmons and Grosier), $A$. helianthicola Rao and Rajagopalan, $A$. longissima Deighton and MacGarvey, A. helianthinficiens Simmons, and A. protenta Simmons $(12,22,26)$. A. helianthi has been recognized as the most prevalent and damaging species worldwide (12). It has been

Corresponding author: C. C. Thanassoulopoulos E-mail: katis@agro.auth.gr

Accepted for publication 5 September 1997.

Publication no. D-1997-1027-04R

(C) 1998 The American Phytopathological Society reported to reduce seed yield by 17 to $26 \%$ (2), $84 \%$ (5), 8 to $60 \%$ (8), 27 to $80 \%$ (12), and 11 to $73 \%$ (23), oil yield by 20 to $28 \%$ (2) and 17 to $33 \%$ (12), oil content of seeds by $2 \%(2)$ and $52 \%$ (5), flower-head diameter by $50 \%$ (5), 1,000-seed weight by $50 \%$ (5), and number of seeds produced per head by $76 \%$ (5).

A. alternata has been reported on sunflower in Brazil (34), India (7), Iran (11), Thailand (22), Bulgaria (6), Greece (31), Italy (33), and the former USSR (30). It often is considered as a disease associated with declining plants and of secondary importance (12), but its significance is in most cases unknown (17). There are several countries, however, where A. alternata is considered important and infection of sunflower by this fungus has received attention. In Iran, for example, the pathogen is considered important enough to warrant control measures $(11,25)$, and in India, where it has been reported to cause severe blight on the crop, the susceptibility of different varieties of sunflower to the fungus was investigated (10) and efforts made to prevent seed-borne infections (21). Several studies have been completed on chemical control of the disease $(12,18,34)$; however, to the authors' knowledge, there have been no attempts to determine potential losses in sunflower yield due to this pathogen.

The fungus also attacks flower-heads, causing head and seed rot $(12,13,18)$. Infection of seeds causes various biochemical changes resulting in degradation of seed components (4). The fungus invades the endosperm and the embryo, reduces seed germination, and can also be seed-borne $(12,27)$.

The objectives of the research presented here were to document the affects of $A$. alternata on production of sunflower and determine if plant debris serves as an overwintering site for the pathogen.

\section{MATERIALS AND METHODS}

Yield loss appraisal was conducted in field experiments during the 1989 to 1993 growing seasons. Trails were conducted on the Farm of the Aristotelian University in Thessaloniki, where epidemics of the disease occur each year. The susceptible Greek oilseed cultivar Kavissos, obtained from the Cotton and Industrial Plants Institute at Sindos in Thessaloniki, was used in all trials. Dates of sowing were 4 April 1989, 5 April 1990, 15 April 1991, 17 April 1992, and 8 April 1993. A single test field that consisted of 15 to $2010-\mathrm{m}$ rows spaced $60 \mathrm{~cm}$ apart was used each year. Seeds were sown $35 \mathrm{~cm}$ apart in the row, resulting in a population of about 50,000 plants $\mathrm{ha}^{-1}$. Plants on the outer rows were not used as test plants. One fifth of the test plants were selected at random and then were sprayed weekly with Dithane M-45 (2.5 g in liter of water) to serve as controls.

All test plants were rated for disease severity caused by A. alternata. Plants damaged by insects or other diseases were not used in evaluations. Observations started two months after sowing, during the vegetative stage V14-V16, according to Schneiter and Miller's scale (24). Disease severity was visually rated on each leaf of every plant following the pictorial assessment key for A. helianthi leaf blight suggested by Allen et al. (3). Plants were tagged at the first observation, and were rated weekly until anthesis was completed (R6 growth stage), or about one month before harvesting. Harvesting took place between August 10 and 15 each year. Flower heads from plants that only had $A$. alternata leaf spot were removed and dried in the sun for 3 days. Threshing of seeds from heads was done manually and the seeds were further dried at room temperature $\left(25^{\circ} \mathrm{C}\right)$ for 1 month. Number of seeds produced per head and seed weight were recorded for every plant. Seeds were counted and cleaned from floral debris by hand, and only plump seeds showing the presence of a kernel were counted.

Disease severity (percentage of leaf area damaged by the fungus) and disease incidence (number of leaves affected) data for each plant were used in combination to determine the disease intensity for the entire plant. A 0 to 5 disease index scale was developed for this purpose (Table 1). Disease incidence was evaluated on four stalk positions, corresponding to leaf positions 1 to 4,5 to 10,11 to 16 , and 17 to 22 , 
starting at the first true leaf. Disease severity of leaves was ranked into three levels: 0 to $1 \%$, more than 1 to $25 \%$, and more than $25 \%$ diseased leaf area. Disease of lower leaves was considered to have less impact on productivity of plants than disease on upper leaves, so a similar level of leaf area damaged resulted in a lower disease index for lower leaves than for upper leaves (Table 1). For example, a diseased leaf area of 0 to $1 \%$ in the basal leaves resulted in a disease index 0 , while in the upper leaves it resulted in disease index 1 , 2 , or 3 depending on stalk position.

Plants graded with the same disease index were grouped, and unequal samples of 6 different disease indices (treatments) were thus formed. Analysis of variance was conducted separately for each year's data according to the completely randomized design, and student's $t$ test was used to test differences among disease indices (28). The relationship between disease index and yield was determined by regression. Test of homogeneity of correlation coefficients, and comparison of regression lines was completed using standard statistical methods $(9,29)$.

Following harvesting in September 1993, diseased leaves were collected, put in a net, and left lying in the field until the following spring. Five hundred conidia of A. alternata were collected from this leaf debris and tested for viability each month from October to April. Viability of conidia was determined by placing them in drops of sterile-distilled water in van Tieghem cells at $25^{\circ} \mathrm{C}$, and checking their germinability after $24 \mathrm{~h}$. Germination of $98 \%$ of the conidia derived from a fresh isolation was used as a reference (32). Simultaneously, 8 to 10 young sunflower plants at a

Table 1. Disease index for sunflower plants infected by Alternaria alternata, derived from number of leaves infected on each plant and disease severity of individual leaves, before anthesis

\begin{tabular}{lcc}
\hline Leaf number (stalk positions) & Diseased leaf area $(\%)$ & Disease index \\
\hline $1-4^{z}$ & $0-1$ & 0 \\
& $>1-25$ & 1 \\
$5-10$ & $>25$ & 2 \\
& $0-1$ & 1 \\
\multirow{2}{*}{$11-16$} & $>1-25$ & 2 \\
& $>25$ & 3 \\
\multirow{2}{*}{$17-22$} & $0-1$ & 2 \\
& $>1-25$ & 3 \\
& $>25$ & 4 \\
& $0-1$ & 3 \\
\hline
\end{tabular}

${ }^{\mathrm{z}}$ Leaves counted upwards, beginning from the first true leaf.

Table 2. Number of seeds produced per head of sunflower infected by Alternaria alternata leaf spot at different levels of disease intensity

\begin{tabular}{lcccc}
\hline Disease index & $\mathbf{1 9 8 9}$ & $\mathbf{1 9 9 1}$ & $\mathbf{1 9 9 2}$ & $\mathbf{1 9 9 3}$ \\
\hline 0 & $1775 \mathrm{a}^{\mathrm{x}}$ & $1856 \mathrm{a}$ & $1881 \mathrm{a}$ & $1596 \mathrm{a}$ \\
1 & $1339 \mathrm{~b}$ & $1406 \mathrm{~b}$ & $1572 \mathrm{~b}$ & $1118 \mathrm{~b}$ \\
2 & $615 \mathrm{c}$ & $1095 \mathrm{c}$ & $1227 \mathrm{c}$ & $796 \mathrm{c}$ \\
3 & $360^{\mathrm{y}}$ & $504^{\mathrm{y}}$ & $405^{\mathrm{y}}$ & $550^{\mathrm{y}}$ \\
4 & $\ldots$ & $\ldots$ & $\ldots$ & $\ldots$ \\
5 & $\ldots$ & $\ldots$ & $\ldots$ & $\ldots$ \\
Number of plants used & $n=64$ & $n=89$ & $n=119$ & $n=41$ \\
\hline
\end{tabular}

${ }^{x}$ Different letters in the same column indicate statistical differences $(P=0.001)$, according to the student's $t$ test.

y One value or mean of two values.

${ }^{\mathrm{z}}$ No plants at this level of disease index.

Table 3. Seed weight per head of sunflower infected by Alternaria alternata leaf spot at different levels of disease intensity

\begin{tabular}{lcccc}
\hline Disease index & $\mathbf{1 9 8 9}$ & $\mathbf{1 9 9 1}$ & $\mathbf{1 9 9 2}$ & $\mathbf{1 9 9 3}$ \\
\hline 0 & $107 \mathrm{a}^{\mathrm{x}}$ & $175 \mathrm{a}$ & $131 \mathrm{a}$ & $104 \mathrm{a}$ \\
1 & $78 \mathrm{a}$ & $140 \mathrm{~b}$ & $112 \mathrm{~b}$ & $51 \mathrm{~b}$ \\
2 & $23 \mathrm{~b}$ & $109 \mathrm{c}$ & $92 \mathrm{c}$ & $33 \mathrm{c}$ \\
3 & $18^{\mathrm{y}}$ & $52^{\mathrm{y}}$ & $42^{\mathrm{y}}$ & $23^{\mathrm{y}}$ \\
4 & $\ldots \ldots^{\mathrm{z}}$ & $\ldots$ & $\ldots$ & $\ldots$ \\
5 & $\ldots$ & $\ldots$ & $\ldots$ & $\ldots$ \\
Number of plants used & $n=64$ & $n=89$ & $n=119$ & $n=41$ \\
\hline
\end{tabular}

${ }^{x}$ Different letters in the same column indicate statistical differences, $(P=0.01)$ according to the student's $t$ test.

y One value or mean of two values.

${ }^{\mathrm{z}}$ No plants at this level of disease index. growth stage V2-V4, were sprayed with a suspension made from the debris and then placed in a moist chamber at $25^{\circ} \mathrm{C}$ for 2 days. Five plants sprayed with sterile, distilled water were used as controls. After 7 days, isolations from spots that developed were made in order to identify the presence of pathogenic A. alternata. Isolations also were made directly from debris onto potato dextrose agar (PDA; OXOID, CM 139).

\section{RESULTS}

Natural infections occurred each year, resulting in low to medium levels of disease intensity. A. alternata was the only species of Alternaria isolated from sunflowers on the University's farm throughout the experimental period. Because of extremely dry weather during the 1990 growing season, only low levels of disease were observed, so data were not collected. During May to mid-June in the other four years, plants completed vegetative growth, and disease indices were mostly 0 to 2 before anthesis, and only a few plants had a disease index rating of 3 . Only a slight progress of the disease was observed during the next stages of growth, obviously due to high temperatures and low levels of humidity which naturally occur in the region. A clear view of disease intensity could be obtained at the late stages of vegetative growth, when all the leaves had been developed. Natural maturity and declining of old lower leaves did not allow estimation of the actual disease intensity during the advanced reproductive stages (after R5 growth stage). The results presented here are derived from disease intensity data collected during development of the last leaves (20 to 22 ), which in this cultivar coincide with the early stages of reproductive growth (R1 to R4 growth stages).

Effective disease control was obtained in the fungicide sprayed plants each year. The number of test plants was dramatically reduced by $M$. phaseolina infections; thus, the final number of plants available for evaluation was low.

The leaf spot disease caused by A. alternata significantly reduced the number of seeds produced per head up to 16 to $65 \%$ (Table 2) and seed weight up to 15 to $79 \%$ (Table 3). Disease intensity was negatively correlated with number of seeds produced per head, and also with seed weight. Number of seeds produced per head was positively correlated $(\mathrm{r}=0.70, P=0.001)$ with seed weight per head (Table 4). Regression lines had the same slope, but belonged to different populations, as was indicated by $b$ statistics (Table 5).

Among 500 conidia taken from sunflower debris monthly from October to April, 94, 89, 76, 68, 27, 44, and 55\%, respectively, germinated in sterile-distilled water at $25^{\circ} \mathrm{C}$ within $48 \mathrm{~h}$. Numerous distorted conidia also were observed in germination. Plants sprayed with a suspension 
made from debris became infected at $25^{\circ} \mathrm{C}$, each month, and A. alternata was successfully re-isolated from lesions. None of the control plants used showed any symptoms. At least 3 different A. alternata isolates were obtained directly from leaf debris; one was identical to the pathogenic isolate in colony appearance, and in size and shape of conidia.

\section{DISCUSSION}

A disease that destroys active leaf area and reduces photosynthetic capacity is expected to affect the plant's productivity. The results of this work indicate that $A$. alternata is capable of reducing the yield of sunflower, and can be as damaging to sunflower as $A$. helianthi $(2,5,8,12,23)$ under certain conditions. Losses in numbers of seeds may be due to fewer plump seeds formed, and not to reduction of achenes. Since the number of seeds per head was positively correlated with seed weight, either yield components may serve as a measure of the negative effect of $A$. alternata leaf spot disease on yield of sunflower. Seed weight seems to be more affected by the disease; however, the number of seeds per head should be preferred for more reliable estimations, as indicated by higher $r$ and $R^{2}$ values than for seed weight. Under the environmental conditions in northern Greece, the most reliable disease intensity estimation can be obtained when all the leaves of the plant are developed, plants are before anthesis, and when natural degradation of lower leaves has started. Yield losses of up to $65 \%$ in number of seeds per head and $79 \%$ in seed weight have demonstrated that $A$. alternata is capable of causing substantial losses under environmental conditions in northern Greece. The disease may be a serious problem in other countries as well; therefore, it should be further investigated in regions where it has been observed.
Data collected in this work did not support the construction of a yield loss model. Statistical differences between regression lines did not permit combination of data collected over years. Such differences are expected due to the high variability of yield among different years in an arable crop. Also, a prediction model of yield reduction should be based on numerous replicates in several areas.

The fungus survived on plant debris under conditions in northern Greece. In addition to the pathogenic A. alternata, 2 more isolates, probably saprophytic, were found in debris. Thus, the actual proportion of germinated conidia which belonged to the pathogenic isolate cannot be clearly estimated. However, the presence of the pathogenic fungus was confirmed by inoculation tests with the sunflower debris.

The same fungus also produces chlamydospores in vitro. Distorted conidia observed in this study were most probably the chlamydospores which have been observed in vitro (14). Conidia retained the ability to germinate within $24 \mathrm{~h}$, even in midwinter (February) when temperatures fell to $-7^{\circ} \mathrm{C}$. Germination of conidia increased after February, indicating that inoculum potential may rise at the beginning of the new growing season.

Recently, this fungus was identified as a distinct pathotype of $A$. alternata that is highly pathogenic on sunflower (15). A. alternata has become a serious pathogen on various crops due to its ability to produce host-specific toxins during pathogenesis $(19,20)$ and the sunflower pathotype of the fungus also was found to produce pathotoxins (16). It appears that $A$. alternata is a threatening pathogen of sunflower under certain conditions. Thus, more research on this disease is needed, including the effects of crop rotation, fungicides, development of genetic resistance, and other control measures.

\section{ACKNOWLEDGMENTS}

We thank the Institute of Cotton and Industrial Plants for providing certified seed of the sunflower cultivar Kavissos, and Mr. Javid Kashefi, student of the Faculty, for his assistance in counting seeds.

\section{LITERATURE CITED}

1. Agricultural Statistics of Greece.1981-1993. National Service of Statistics Editions, Athens 1991-1994.

2. Allen, S. J., Kochman, J. K., and Brown, J. F. 1981. Losses in sunflower yield caused by Alternaria helianthi in southern Queensland. Aust. J. Agric. Anim. Husb. 21:98-100.

3. Allen, S. J., Brown, J. F., and Kochman, J. K. 1983. Production of inoculum and field assessment of Alternaria helianthi on sunflower. Plant Dis. 67:665-668.

4. Ataga, A. E., and Akueshi, C. O. 1986 Changes in oil and free fatty acid contents of sunflower seeds inoculated with Alternaria tenuis Auct., Curvularia lunata (Wakker) Boedijin, Fusarium moniliforme Sheld and Macrophomina phaseolina (Tassi) Goid. Phytopathol. Mediterr. 25:44-46.

5. Balasubrahmanyam, N., and Kolte, S. J. 1980. Effect of different intensities of Alternaria blight on yield and oil content of sunflower J. Agric. Sci. Camb. 94:749-751.

6. Bachvarova, R. 1977. Alternariozata po slanchogleda - nova bolest u nas. (Alternaria blight of sunflower, a new disease in Bulgaria.) Rastit. Zasht. 25:23-24 (Bg).

7. Bose, A. B. 1942. Alternaria on leaves of sunflower in India. J. Indian Bot. Soc. 21:179-184.

8. Carson, M. L. 1985. Epidemiology and yield losses associated with Alternaria blight of sunflower. Phytopathology 75:1151-1156.

9. Draper, N. R., and H. Smith. 1966. Applied Regression Analysis. John Wiley and Sons Inc., New York.

10. Gupta, Y. K., Gupta, M. N., and Roy, A. N. 1978. Reaction of sunflower varieties to $\mathrm{Al}$ ternaria alternata. Indian Phytopathol. 31:507-508.

11. Hedjaroude, G. A. 1973. La maladie des taches brunes du tournesol (Helianthus annuus L.) en Iran. Phytopathol. Z. 78:274-277.

12. Kolte, S. J. 1985. Diseases of annual edible oilseed crops. Pages 9-96 in: Sunflower, Safflower and Nigerseed Diseases. Vol. III. CRC Press.

13. Kumar, Y., and Dwivedi, R. S. 1981. Myco-

Table 4. Correlation coefficients and coefficients of determination for regressions of disease index and yield components of sunflower plants infected by Alternaria alternata leaf spot

\begin{tabular}{|c|c|c|c|c|c|c|c|}
\hline \multicolumn{8}{|c|}{ Disease index } \\
\hline \multicolumn{4}{|c|}{ Number of seeds per head } & \multicolumn{4}{|c|}{ Seed weight per head } \\
\hline 1989 & 1991 & 1992 & 1993 & 1989 & 1991 & 1992 & 1993 \\
\hline $\begin{array}{c}r=-0.69^{\mathrm{z}} \\
R^{2}=0.47\end{array}$ & $\begin{array}{c}r=-0.82^{\mathrm{z}} \\
R^{2}=0.66\end{array}$ & $\begin{array}{c}r=-0.81^{\mathrm{z}} \\
R^{2}=0.64\end{array}$ & $\begin{array}{c}r=-0.82^{\mathrm{z}} \\
R^{2}=0.66\end{array}$ & $\begin{array}{c}r=-0.55^{\mathrm{z}} \\
R^{2}=0.29\end{array}$ & $\begin{array}{c}r=-0.67^{\mathrm{z}} \\
R^{2}=0.45\end{array}$ & $\begin{array}{c}r=-0.47^{\mathrm{z}} \\
R^{2}=0.22\end{array}$ & $\begin{array}{r}r=-0.69^{\mathrm{z}} \\
R^{2}=0.40\end{array}$ \\
\hline
\end{tabular}

${ }^{\mathrm{z}}$ Significant at $P=0.001$.

Table 5. Comparison of regressions between disease index and yield components of sunflower affected by Alternaria alternata leaf spot

\begin{tabular}{|c|c|c|c|c|c|}
\hline \multicolumn{6}{|c|}{ Disease index } \\
\hline \multicolumn{3}{|c|}{ Number of seeds per head } & \multicolumn{3}{|c|}{ Seed weight per head } \\
\hline Coefficient of regression (b) & Slope & Intercept & Coefficient of regression (b) & Slope & Intercept \\
\hline $\begin{array}{l}\mathrm{b}_{1989}=-521.23 \\
\mathrm{~b}_{1991}=-390.25 \\
\mathrm{~b}_{1992}=-341.20 \\
\mathrm{~b}_{1993}=-355.17\end{array}$ & $\begin{array}{l}\mathrm{a}^{\mathrm{z}} \\
\mathrm{a} \\
\mathrm{a} \\
\mathrm{a}\end{array}$ & $\begin{array}{l}\mathrm{ab} \\
\mathrm{b} \\
\mathrm{c} \\
\mathrm{a}\end{array}$ & $\begin{array}{l}\mathrm{b}_{1989}=-36.39 \\
\mathrm{~b}_{1991}=-33.65 \\
\mathrm{~b}_{1992}=-20.45 \\
\mathrm{~b}_{1993}=-26.79\end{array}$ & $\begin{array}{l}\mathrm{a} \\
\mathrm{a} \\
\mathrm{a} \\
\mathrm{a}\end{array}$ & $\begin{array}{l}\mathrm{a} \\
\mathrm{b} \\
\mathrm{b} \\
\mathrm{a}\end{array}$ \\
\hline
\end{tabular}

${ }^{\mathrm{z}}$ Different letters in the same column indicate statistical differences at $P=0.05$. 
flora associated with floral parts of sunflower. Indian Phytopathol. 34:314-317.

14. Lagopodi, A. L., and Thanassoulopoulos, C. C. 1995. Development of chlamydospores in Alternaria alternata. Mycologia 87:588-591.

15. Lagopodi, A. L., and Thanassoulopoulos, C. C. 1996. Alternaria alternata f. sp. helianthina: a new pathotype of the fungus causing Alternaria leaf spot to sunflower. J. Phytopathology, 144:571-573.

16. Likopoulou-Kyriakides, M., Lagopodi, A. L., Thanassoulopoulos, C. C., Stavropoulos, G., and Magafa V. 1996. Isolation and synthesis of a host-selective toxin produced by an $\mathrm{Al}$ ternaria alternata isolate pathogenic to sunflower. Phytochemistry 45:37-40.

17. McMullen, M. P. 1985. Sunflower production and pest management. Ext. Bull. 25. North Dakota State University, Fargo.

18. Narain, U., and Saksena , H. K. 1981. Leaf spot and head rot of sunflower caused by $A l$ ternaria alternata. Indian Phytopathol. 34:128.

19. Nishimura, S., and Kohmoto, K. 1983. Host specific toxins and chemical structures from Alternaria species. Annu. Rev. Phytopathol. 21:87-116.

20. Nishimura, S., Vance, C. P., and Doke, N. 1987. Molecular determinants of plant dis- eases. Japan Scientific Societies Press, Tokyo, Springer-Verlag, Berlin.

21. Prasad, R. K., and Das, S. R. 1986. Effect of methox- ethyl mercury chloride on control of seed- borne Alternaria leaf-blight of sunflower. Seed Res. 14:248-249.

22. Prathuangwong, S., Kao, S. W., Sommartya, T., and Sinchaisri, P. 1991. Role of four Alternaria spp. causing leaf and stem blight of sunflower in Thailand and their chemical controls. Kasetsart J. Natur. Sci. 25:112-124.

23. Reddy, P. C., and Gupta, B. M. 1977. Disease loss appraisal due to leaf blight of sunflower indicated by Alternaria helianthi. Indian Phytopathol. 30:569-570.

24. Schneiter, A. A., and Miller, J. F. 1981. Description of sunflower growth stages. Crop Sci. 21:901-903.

25. Sharifi-Tehrani, A. 1973. Effects of five organic and inorganic fungicides on brown spot (Alternaria tenuis Nees) of sunflower. Iran. J. Plant Pathol. 9:12-18.

26. Simmons, E. G. 1986. Alternaria themes and variations (17-21). VII. Some species of Alternaria on Helianthus. Mycotaxon 25:203216.

27. Singh, S., Mathur B., and Neergaard P. 1977. Histopathology of sunflower seeds infected by Alternaria tenuis. Seed Sci. Technol.
5:579-585.

28. Snedecor, G. W., and W. G. Cochran. 1980 Statistical methods. Seventh edition. The Iowa State University press, Ames.

29. Steel, R. G., and J. H. Torrie. 1980. Principals and Procedures of Statistics, a Biometrica Approach. Second edition. McGraw-Hill Book Company, New York.

30. Svetov, V. G. 1975. Al'ternarioz podsolnechnika na Kubani. (Alternaria blight of sunflower along the Kuban river.) Mikol. Fitopatol. 9:418-421 (Ru).

31. Thanassoulopoulos, C. C. 1987. New diseases of various crops in Greece. FAO Plant Prot. Bull. 35:164.

32. Thanassoulopoulos, C. C., and Kolokoussi, A. T. 1988. A new Alternaria disease of sunflower in Greece. Proceedings of the 12th International Sunflower Conference, Novi Sad Yugoslavia July 25 to 29, Vol. II. International Sunflower Association.

33. Tosi, L., and Zazzerini, A. 1991. Alternaria helianthi nuovo parassita del girasole in Italia. Inform. Fitopatol. 4:54-58.

34. Ungaro, M. R. G., and Azevedo, J. L. 1984 Controle de Alternaria alternata in vitro com zineb, captan e benomil. (Control of Alternaria alternata in vitro with zineb, captan, and benomyl.) Fitopatol. Bras. 9:89-100 (Pt). 